\title{
Effects of Early Amino Acid Administration on Leucine and Glucose Kinetics in Premature Infants
}

\author{
CHRIS H.P. VAN DEN AKKER, FRANS W.J. TE BRAAKE, DARCOS J.L. WATTIMENA, GARDI VOORTMAN, \\ HENK SCHIERBEEK, ANDRAS VERMES, AND JOHANNES B. VAN GOUDOEVER
}

\author{
Department of Pediatrics [C.H.P.A., F.W.J.B., H.S., J.B.G.], Department of Internal Medicine [D.J.L.W., G.V.], Department of Clinical \\ Pharmacy [A.V.], Erasmus MC-Sophia Children's Hospital, 3000 CB Rotterdam, The Netherlands
}

\begin{abstract}
We previously showed that, in prematurely born infants, an anabolic state without metabolic acidosis can be achieved upon intravenous amino acid (AA) administration in the immediate postnatal phase, despite a low energy intake. We hypothesized that the anabolic state resulted from an increased protein synthesis and not a decreased proteolysis. Furthermore, we hypothesized that the energy needed for the higher protein synthesis rate would be derived from an increased glucose oxidation. To test our hypotheses, 32 ventilated premature infants $(<1500 \mathrm{~g})$ received intravenously either solely glucose or glucose and $2.4 \mathrm{~g} \mathrm{AA} / \mathrm{kg} / \mathrm{d}$ immediately postnatally. On postnatal d 2, each group received primed continuous infusions of either $\left[1-{ }^{13} \mathrm{C}\right]$ leucine or $\left[\mathrm{U}-{ }^{13} \mathrm{C}_{6}\right]$ glucose. ${ }^{13} \mathrm{CO}_{2}$ enrichments in expiratory air and plasma $\left[1-{ }^{13} \mathrm{C}\right] \alpha$-KICA (as an intracellular leucine precursor) and $\left[\mathrm{U}_{-}{ }^{13} \mathrm{C}_{6}\right]$ glucose enrichments were measured by mass spectrometry techniques. The AA administration resulted in an increased incorporation of leucine into body protein and a higher leucine oxidation rate, whereas leucine release from proteolysis was not affected. Glucose oxidation rate did not increase upon AA administration. In conclusion, the anabolic state resulting from AA administration in the immediate postnatal period resulted from increased protein synthesis and not decreased proteolysis. The energy needed for the additional protein synthesis was not derived from an increased glucose oxidation. (Pediatr Res 59: 732-735, 2006)
\end{abstract}

A series of studies on AA administration in premature infants within the first few postnatal days show a positive effect on nitrogen retention or plasma AA concentrations starting immediately after birth $(1,2)$, within or at $24 \mathrm{~h}$ postnatally (3-5), or later (6). In our latest study regarding early AA administration, we administered $2.4 \mathrm{~g} \mathrm{AA} / \mathrm{kg} / \mathrm{d}$ to one half of 136 VLBW infants within $2 \mathrm{~h}$ postnatally (1). This resulted in a positive nitrogen balance and converted plasma AA concentrations to levels fitting reference ranges. Furthermore, there were no major metabolic disturbances in comparison with the group receiving solely glucose.

However, nitrogen balance calculations provide no information on how a particular nutritional status was reached. An anabolic state can arise from increased protein synthesis, decreased protein breakdown, or a combination of both. To clarify the mechanism by which an anabolic state is reached in

Received September 7, 2005; accepted January 5, 2006.

Correspondence: J.B. van Goudoever, M.D., Ph.D., Erasmus MC-Sophia Children's Hospital, room sp-3432, PO box 2060, 3000 CB Rotterdam, The Netherlands; e-mail: j.vangoudoever@erasmusmc.nl

C.H.P.A. and F.W.J.B. contributed equally to this article.

DOI: $10.1203 / 01$.pdr.0000214990.86879.26
VLBW infants, we conducted in a first trial a stable isotope study using $\mathrm{L}-\left[1-{ }^{13} \mathrm{C}\right]$ leucine. We speculated that the anabolic state would have been induced by an increased protein synthesis, a phenomenon also observed in other studies, none of which, however, started AA supplementation immediately after birth $(3,4,6)$. Furthermore, by collecting ${ }^{13} \mathrm{CO}_{2}$ we were able to quantify leucine oxidation rates.

We hypothesized that the extra energy required for protein synthesis would be derived from additional glucose oxidation. Therefore, we studied glucose metabolism in a second trial in which infants also received either solely glucose or glucose and AA, using $\mathrm{D}-\left[\mathrm{U}_{-}{ }^{13} \mathrm{C}_{6}\right]$ glucose as a tracer.

\section{METHODS}

Study. The included infants were a subset of the patients included earlier by Te Braake et al. (1) in a study determining safety and efficacy of high-dose early AA administration. The present study was designed as a randomized open trial and was performed in the neonatal intensive care unit of the Erasmus MC-Sophia Children's Hospital, Rotterdam, the Netherlands. The study was investigator initiated with no funding from industry. The protocol was approved by the Erasmus MC Medical Ethical Committee and parental consent was obtained before the study.

Patients. Thirty-two prematurely born infants with a birth weight $<1500 \mathrm{~g}$, who were born in the Erasmus MC-Sophia Children's Hospital, were mechanically ventilated, had an arterial catheter, and were expected to be completely dependent on parenteral nutrition for the first $2 \mathrm{~d}$ of life, were directly after birth randomly assigned to receive either i) only glucose during the first $2 \mathrm{~d}$ (control group, $n=16$ ) or ii) glucose and $2.4 \mathrm{~g}$ of protein $/ \mathrm{kg} / \mathrm{d}$ as AA (Primene 10\%, Baxter, Clintec Benelux N.V., Brussels, Belgium) within $2 \mathrm{~h}$ postnatally (intervention group, $n=16$ ).

AA and/or glucose solutions were constantly infused without interruptions during the study. Lipids and/or (minimal) enteral feedings were not administered until after the study period. Exclusion criteria were known congenital abnormalities, chromosome defects, and metabolic, endocrine, renal, or hepatic disorders. For all infants, we recorded birth weight, gestational age, SD scores for weight (7), antenatal corticosteroid usage, and severity of illness at entry of the study by means of Apgar and CRIB scores (8). We also assessed blood gases and nitrogen balances as described previously (1).

The control and intervention groups were each subdivided into two cohorts ( $n=8$ each). In one cohort (A), we studied the effects of early AA administration on leucine kinetics on postnatal d 2. In the other cohort (B), we determined glucose kinetics on d 2 upon early AA administration.

Stable isotopes. $\left[{ }^{13} \mathrm{C}\right]$ Sodium bicarbonate $\left(\mathrm{NaH}^{13} \mathrm{CO}_{3}\right)(99 \%$ enriched), $\mathrm{L}-\left[1-{ }^{13} \mathrm{C}\right]$ leucine (99\% enriched), and D- $\left[\mathrm{U}-{ }^{13} \mathrm{C}_{6}\right]$ glucose (99\% enriched) were purchased from Cambridge Isotope Laboratories (Andover, MA) and were

Abbreviations: $\boldsymbol{\alpha}$-KICA, $\alpha$-keto-isocaproic-acid; AA, amino acid(s); GPR, glucose production rate; LRP, leucine release from protein; NOGD, nonoxidative glucose disposal; NOLD, nonoxidative leucine disposal; VLBW, very low birth weight 
diluted with a $0.9 \%$ saline solution by the hospital's pharmacy after which it was tested on sterility and pyrogenicity. For the leucine study, the bicarbonate pool was initially enriched with a primed $(10 \mu \mathrm{mol} / \mathrm{kg})$ continuous $\mathrm{NaH}^{13} \mathrm{CO}_{3}$ infusion $(10 \mu \mathrm{mol} / \mathrm{kg} / \mathrm{h})$. After $2 \mathrm{~h}$, the infusion was replaced by a primed $(15$ $\mu \mathrm{mol} / \mathrm{kg}$ ) continuous L- $\left[1-{ }^{13} \mathrm{C}\right]$ leucine infusion $(15 \mu \mathrm{mol} / \mathrm{kg} / \mathrm{h})$ lasting for $5 \mathrm{~h}$ (Fig. 1A)

In the second cohort (the glucose study), the bicarbonate pool was also enriched with a primed $(15 \mu \mathrm{mol} / \mathrm{kg})$ continuous $\mathrm{NaH}^{13} \mathrm{CO}_{3}$ infusion (15 $\mu \mathrm{mol} / \mathrm{kg} / \mathrm{h}$ ). After $2 \mathrm{~h}$, the infusion was replaced by a primed $\left(10 \mu \mathrm{mol} / \mathrm{kg}\right.$ ) continuous D-[U- $\left.{ }^{13} \mathrm{C}_{6}\right]$ glucose infusion $(5 \mu \mathrm{mol} / \mathrm{kg} / \mathrm{h})$ lasting for $6 \mathrm{~h}$ (Fig. 1B).

Tracers were infused with a Perfusor fm infusion pump (B|Braun Medical B.V., Oss, the Netherlands) along the same infusion route as the parenterally administered nutrients.

Measurement of isotopic enrichments in plasma. Arterial blood samples were drawn once before the isotope infusions (baseline) and twice during the last hour of the leucine or glucose tracer infusion. After collection, the samples were put on melting ice immediately and centrifuged, after which the plasma was aspired and stored at $-80^{\circ} \mathrm{C}$ until analysis.

Within the cell, leucine is reversibly transaminated to its keto-analogue, $\alpha$-KICA. The plasma enrichment of $\left[1-{ }^{13} \mathrm{C}\right] \alpha$-KICA is very close to intracellular $\left[1-{ }^{13} \mathrm{C}\right]$ leucine enrichment. Measurement of the enrichment of $\left[1-{ }^{13} \mathrm{C}\right] \alpha-$ KICA after L- $\left[1-{ }^{13} \mathrm{C}\right]$ leucine infusion will, therefore, reflect both the site of incorporation of leucine in protein and the site for the irreversible decarboxylation of $\left[1-{ }^{13} \mathrm{C}\right] \alpha$-KICA to isovaleryl-CoA and ${ }^{13} \mathrm{CO}_{2}(9,10)$.

Samples (50 $\mu \mathrm{L}$ plasma) were treated and analyzed as previously described $(2,11)$. The ${ }^{13} \mathrm{C}$ enrichment of $\alpha$-KICA was, after derivatization to butyldimethyl-silylquinoxalinol derivatives, determined with a Carlo Erba GC8000 gas chromatograph coupled to a Fisons MD800 mass spectrometer (Interscience BV, Breda, the Netherlands) by measuring the intensity of the 259 and 260 fragments in electron impact ionization mode.

The $\left[\mathrm{U}-{ }^{13} \mathrm{C}_{6}\right.$ ]glucose enrichment of the glucose aldonitril pentaacetate derivatives was monitored, after combustion to carbon dioxide at mass 44 for ${ }^{12} \mathrm{CO}_{2}$ and mass 45 for ${ }^{13} \mathrm{CO}_{2}$, using a gas chromatograph combustion isotope ratio mass spectrometer (GC-C-IRMS) (Delta XP, Thermo Electron, Bremen, Germany).

Oxidation measurements. To determine the fractions of leucine or glucose oxidized, approximately $15 \mathrm{~mL}$ of expiratory air was collected in a vacuum tube at the outlet of the ventilator: two times in duplicate before the isotope infusion (baseline), five times in duplicate during the last hour of the $\mathrm{NaH}^{13} \mathrm{CO}_{3}$ infusion, and five times in duplicate during the last hour of the labeled leucine or glucose infusion. We assumed an equal $\mathrm{CO}_{2}$ production and retention during the sodium bicarbonate and leucine or sodium bicarbonate and glucose infusions. Breath samples were analyzed for ${ }^{13} \mathrm{CO}_{2}$ enrichment on an isotope ratio mass spectrometer (IRMS) (ABCA, Europe Scientific, Van Loenen Instruments, Leiden, the Netherlands).

Calculations. The turnover rates were calculated by measuring tracer dilution in plasma at steady state with standard isotope equations, as previously described for leucine (2) and glucose (12) studies.

Statistics. Based on previous findings from our study group, we calculated that with an $\alpha$ of 0.05 , a power of 0.80 , and a difference in protein synthesis rate of $1.4 \mathrm{~g} / \mathrm{kg} / \mathrm{d}$ with an SD of 0.8 , group size in the leucine study needed to be at least six to detect a difference (6). A statistically detectable increment in glucose oxidation of $2.0 \mathrm{mg} / \mathrm{kg} / \mathrm{min}$ with an SD of 1.0 would also require six infants in each group to be studied (12). However, both in the leucine and the glucose studies, we included eight infants in the intervention and control groups and the control groups to increase power.

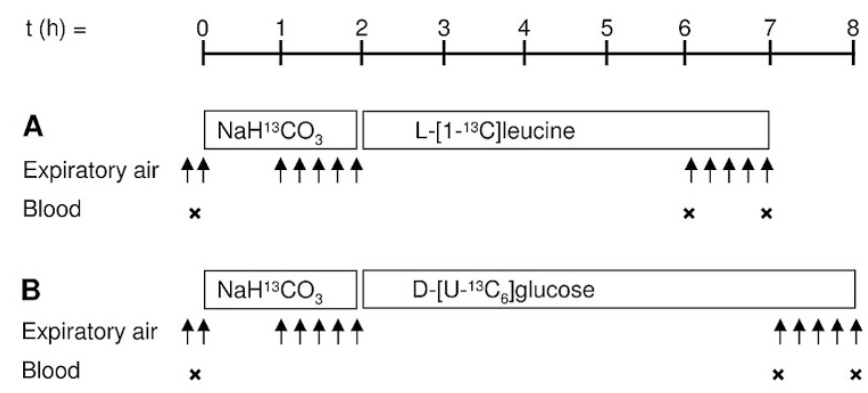

Figure 1. Study design. Infants in both the control and intervention group were subjected to either the labeled leucine $(A)$ or the labeled glucose (B) protocol on postnatal d 2.
One-way ANOVA was used to detect differences between group characteristics, clinical laboratory measurements, and nutritional intakes between the four subgroups. Differences between intervention and control groups were tested by $t$ tests, Mann-Whitney tests, and $\chi^{2}$ tests, as appropriate, using SPSS version 11.0 (SPSS Inc., Chicago, IL). Depending on distribution and type of test, values are expressed as mean $\pm \mathrm{SD}$, as median (25th to 75th percentile), or as percentage, respectively. Significance level was set at $p<0.05$.

\section{RESULTS}

We included 32 infants, of whom 7 were small for gestational age $(<-2 \mathrm{SD})$. Patient characteristics are provided in Table 1. Overall, the infants in the intervention group had, by coincidence, received antenatal steroids more often than those in the control group. AA administration to the infants in the intervention group started within $2 \mathrm{~h}$ postnatally. The stable isotope study was started on the second postnatal day, i.e., between 20 and $44 \mathrm{~h}$ after birth. Isotopic steady state in ${ }^{13} \mathrm{CO}_{2}$ excretion in expiratory air was reached in all infants during the last hour of each infusion (Fig. 2).

The actual protein intakes at time of study were $0 \pm 0$ and $2.32 \pm 0.08 \mathrm{~g} / \mathrm{kg} / \mathrm{d}(p<0.001)$ and the nonprotein energy intakes (solely glucose) were $34 \pm 8$ and $30 \pm 6 \mathrm{kcal} / \mathrm{kg} / \mathrm{d}$ $(p=0.103)$ in the control and intervention groups, respectively. Other relevant patient data are provided in Table 2.

Inasmuch as we only performed a power calculation on protein synthesis and glucose oxidation rates, all other outcomes should be regarded as hypothesis-generating data.

Leucine kinetic data are displayed in Figure 3. Infants in the intervention group had a higher leucine flux, NOLD rate (indicative of protein synthesis), and oxidation rate. The LRP rate (indicative of protein breakdown) was not altered. Leucine balance improved significantly in the infants receiving AA $(p<0.001)$. The control group had a negative balance, whereas the balance in the intervention group was not different from zero.

The glucose kinetic data are outlined in Figure 4. AA administration did not have any significant effects on glucose metabolism with regard to GPR, flux, oxidation, and NOGD rate.

In both groups, GPR (gluconeogenesis or glycogenolysis) was not completely inhibited, despite a mean intake of $5.7 \pm$ $1.2 \mathrm{mg}$ glucose $/ \mathrm{kg} / \mathrm{min}$ during the study period. In the control group, $75 \%$ of the glucose flux was oxidized; in the intervention group, this fraction amounted to $84 \%(p=0.185)$. The absolute amount of oxidized glucose did not differ signifi-

Table 1. Clinical characteristics of the infants in the control and intervention groups

\begin{tabular}{lcc}
\hline & Control & Intervention \\
\hline No. $($ male/female $)$ & $16(9 / 7)$ & $16(8 / 8)$ \\
Birth weight $(\mathrm{g})^{*}$ & $949 \pm 231$ & $923 \pm 192$ \\
Gestational age $(\mathrm{wk})^{*}$ & $27.4 \pm 1.4$ & $27.3 \pm 1.8$ \\
SD score for weight* & $-0.9 \pm 1.4$ & $-1.0 \pm 1.3$ \\
CRIB score $\dagger$ & $6(3-9)$ & $5(2-7)$ \\
Apgar score $(5$ min $) \dagger$ & $8(7-9)$ & $9(8-9)$ \\
Antenatal corticosteroids & $8 / 6 / 2$ & $2 / 4 / 10$ \\
$\quad(0 / 1 / 2$ doses $)$ & & \\
\hline
\end{tabular}

CRIB is clinical risk index for babies (10).

$*$ Values are expressed as mean $\pm \mathrm{SD}$.

$\dagger$ Values are expressed as median (25th to 75 th percentile). 


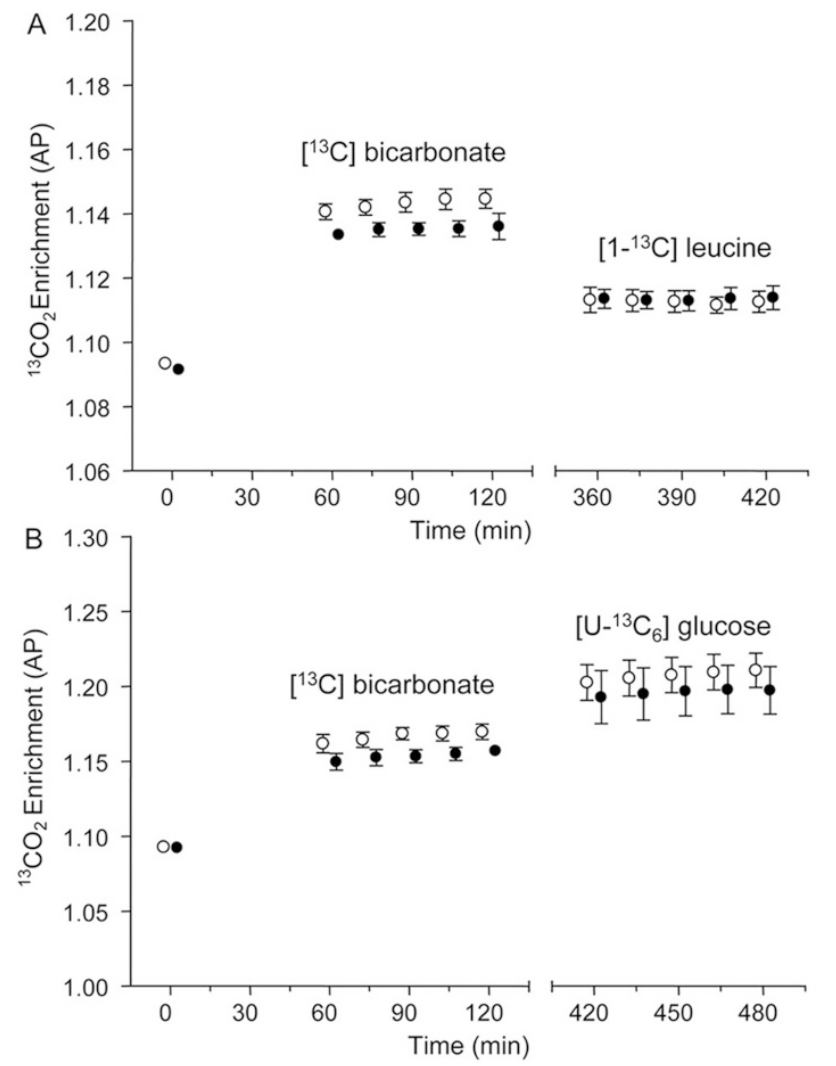

Figure 2. ${ }^{13} \mathrm{CO}_{2}$ excretion curve during the leucine $(A)$ and glucose $(B)$ experiment. Enrichment is represented in atom percent $(A P)$ as mean $\pm \mathrm{SD}$ control $(\bigcirc)$, intervention $(\bullet)$.

cantly between groups $(5.3 \pm 1.3 \mathrm{mg} / \mathrm{kg} / \mathrm{min}$ and $5.8 \pm 1.4$ $\mathrm{mg} / \mathrm{kg} / \mathrm{min}$, respectively; $p=0.462$ ).

\section{DISCUSSION}

We found that AA administration at a relatively high dose from birth onward exerted its anabolic effect through increased protein synthesis and not decreased proteolysis. The additional energy needed was not derived from glucose, but could, at least partially, be derived from a concomitant increase in AA oxidation.

Most studies in premature infants, including the present, show a positive effect of AA administration on protein accretion caused by an increased synthesis rate $(3,4,6,13)$. Also, in the ovine fetus, AA administration does have a beneficial effect on protein accretion by increasing protein synthesis

Table 2. Study parameters on the second day of life in the control and intervention groups

\begin{tabular}{lcc}
\hline & Control & Intervention \\
\hline Glucose intake $(\mathrm{mg} / \mathrm{kg} / \mathrm{min})$ & $5.9 \pm 1.3$ & $5.2 \pm 1.0$ \\
Glucose concentration $(\mathrm{mmol} / \mathrm{L})$ & $6.1(4.2-6.9)$ & $4.6(3.7-5.4)$ \\
Nitrogen balance $(\mathrm{mg} \mathrm{N} / \mathrm{kg} / \mathrm{d})$ & $-99 \pm 42$ & $151 \pm 105^{*}$ \\
$\mathrm{pH}$ & $7.31 \pm 0.05$ & $7.30 \pm 0.07$ \\
Base excess $(\mathrm{mmol} / \mathrm{L})$ & $-4.4 \pm 1.3$ & $-5.4 \pm 2.0$ \\
Blood urea nitrogen $(\mathrm{mmol} / \mathrm{L})$ & $6.2 \pm 1.5$ & $9.7 \pm 2.6^{*}$ \\
\hline
\end{tabular}

Values given as mean $\pm \mathrm{SD}$, except for glucose concentration [median (25th to 75 th percentile)].

* Statistically significant, $p<0.05$.

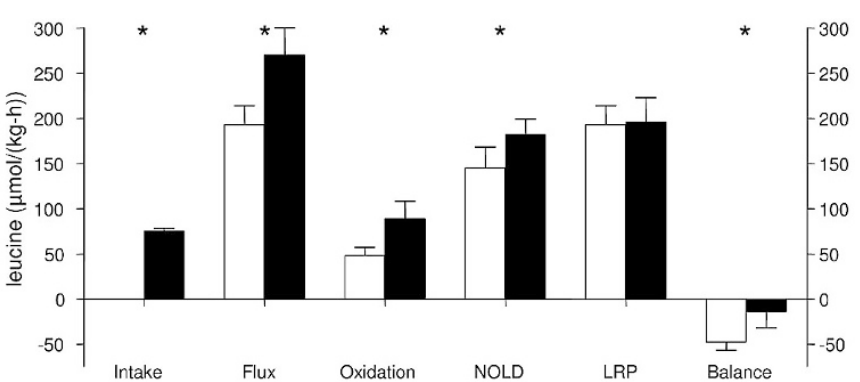

Figure 3. Leucine kinetics. Data from the $\left[1-{ }^{13} \mathrm{C}\right]$ leucine infusion protocol (A) on postnatal d 2 in infants in the control $(\square, n=8)$ and intervention ( $\square$, $n=8$ ) groups. Bars represent mean $\pm \mathrm{SD}$. NOLD represents protein synthesis. LRP represents protein breakdown. *Statistically significant, $p<$ 0.05 .

while leaving proteolysis unaltered (14). One study, however, investigating a short-term change in nutritional regimen, found a simultaneous decrease in proteolysis (15).

Anabolism in adults $(16,17)$ and healthy term infants $(18,19)$, unlike in preterm infants and ovine fetuses, is predominantly achieved by suppression of proteolysis instead of protein synthesis. Possibly, a new balance between protein breakdown and synthesis is developing during early life, explaining this observed discrepancy.

We found a positive nitrogen balance, not only in the intervention group of the 135 infants studied earlier (1), but also in the intervention group of the leucine cohort in this study. However, the leucine balance was not significantly different from zero. Nevertheless, there is still a significant correlation between both balance methods $\left(r^{2}=0.47, p=\right.$ $0.003)$. This discrepancy, which we and others noted before $(2,4)$, might be explained by the relative abundance of leucine in parenteral AA solutions relative to the occurrence of leucine in body protein. Because the rate of protein deposition is controlled by the rate-limiting AA in the AA solution, all excess AA are oxidized. Leucine in particular might be oxidized pro rata more than other AA, explaining a negative leucine balance despite a positive nitrogen balance. On the other hand, the difference between the stable isotope and nitrogen balance techniques could also be partially due to the tendency to overestimate nitrogen retention (20).

In our study, early AA administration had hardly any effect on glucose metabolism. Glucose oxidation, NOGD, and GPR were unaltered. In adults, AA supplementation, and thus provision of gluconeogenic substrates, was found to result in

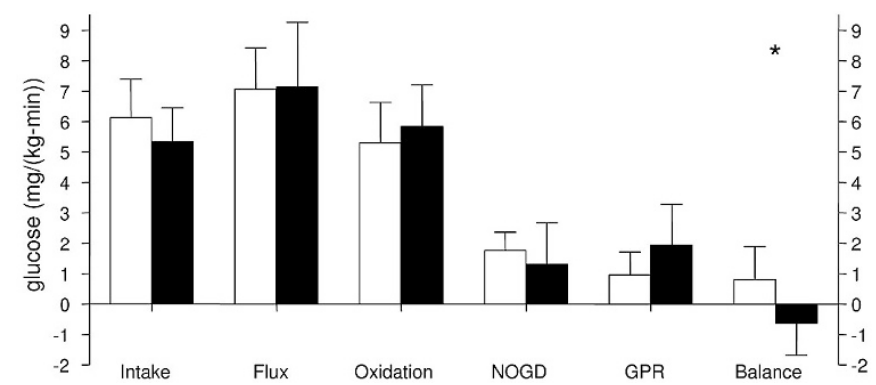

Figure 4. Glucose kinetics. Data from the $\left[\mathrm{U}_{-}{ }^{13} \mathrm{C}_{6}\right]$ glucose infusion protocol (B) on postnatal d 2 in infants in the control $(\square, n=8)$ and intervention ( $\square$, $n=8)$ groups. Bars represent mean $\pm \mathrm{SD}$. $*$ Statistically significant, $p<0.05$. 
an increased endogenous GPR (21). This contrasts with findings in premature neonates from the study by Poindexter et al. (13) and the present study. Like in adults, we expected to find a higher glucose oxidation rate for generating the energy needed for extra protein synthesis after AA administration. Poindexter et al. (13), using indirect calorimetry, also suggested a higher glucose oxidation rate after AA had been introduced, inasmuch as the respiratory quotient increased. Surprisingly, we could not detect any difference in oxidation rate. The source of the needed extra energy remains, therefore, speculative. Nevertheless, the higher leucine oxidation rate might reflect that AA oxidation itself might provide some of the energy needed. Other sources of energy could include fatty acids and ketone bodies.

In conclusion, AA administration to premature infants from birth onward reverses the catabolic state that is otherwise obtained when AA are withheld. Particularly protein synthesis rate especially is increased. The additional energy needed for this process is not derived from glucose oxidation.

\section{REFERENCES}

1. te Braake FW, van den Akker CH, Wattimena DJ, Huijmans JG, van Goudoever JB 2005 Amino acid administration to premature infants directly after birth. J Pediatr 147:457-461

2. Van Goudoever JB, Colen T, Wattimena JL, Huijmans JG, Carnielli VP, Sauer PJ 1995 Immediate commencement of amino acid supplementation in preterm infants: effect on serum amino acid concentrations and protein kinetics on the first day of life. J Pediatr 127:458-465

3. Thureen PJ, Melara D, Fennessey PV, Hay WWJr 2003 Effect of low versus high intravenous amino acid intake on very low birth weight infants in the early neonatal period. Pediatr Res 53:24-32

4. Rivera AJr., Bell EF, Bier DM 1993 Effect of intravenous amino acids on protein metabolism of preterm infants during the first three days of life. Pediatr Res 33:106-111

5. Saini J, MacMahon P, Morgan JB, Kovar IZ 1989 Early parenteral feeding of amino acids. Arch Dis Child 64:1362-1366
6. van Lingen RA, van Goudoever JB, Luijendijk IH, Wattimena JL, Sauer PJ 1992 Effects of early amino acid administration during total parenteral nutrition on protein metabolism in pre-term infants. Clin Sci (Lond) 82:199-203

7. Usher R, McLean F 1969 Intrauterine growth of live-born Caucasian infants at sea level: standards obtained from measurements in 7 dimensions of infants born between 25 and 44 weeks of gestation. J Pediatr 74:901-910

8. 1993 The CRIB (clinical risk index for babies) score: a tool for assessing initial neonatal risk and comparing performance of neonatal intensive care units. The International Neonatal Network. Lancet 342:193-198

9. Matthews DE, Schwarz HP, Yang RD, Motil KJ, Young VR, Bier DM 1982 Relationship of plasma leucine and alpha-ketoisocaproate during a L-[1-13C]leucine infusion in man: a method for measuring human intracellular leucine tracer enrichment. Metabolism 31:1105-1112

10. Thompson GN, Pacy PJ, Ford GC, Merritt H, Halliday D 1988 Relationships between plasma isotope enrichments of leucine and alpha-ketoisocaproic acid during continuous infusion of labelled leucine. Eur J Clin Invest 18:639-643

11. Leij-Halfwerk S, Dagnelie PC, van Den Berg JW, Wattimena JD, Hordijk-Luijk CH, Wilson JP 2000 Weight loss and elevated gluconeogenesis from alanine in lung cancer patients. Am J Clin Nutr 71:583-589

12. van Goudoever JB, Sulkers EJ, Chapman TE, Carnielli VP, Efstatopoulos T, Degenhart HJ, Sauer PJ 1993 Glucose kinetics and glucoregulatory hormone levels in ventilated preterm infants on the first day of life. Pediatr Res 33:583-589

13. Poindexter BB, Karn CA, Leitch CA, Liechty EA, Denne SC 2001 Amino acids do not suppress proteolysis in premature neonates. Am J Physiol Endocrinol Metab 281:E472-E478

14. Liechty EA, Boyle DW, Moorehead H, Auble L, Denne SC 1999 Aromatic amino acids are utilized and protein synthesis is stimulated during amino acid infusion in the ovine fetus. J Nutr 129:1161-1166

15. Clark SE, Karn CA, Ahlrichs JA, Wang J, Leitch CA, Leichty EA, Denne SC 1997 Acute changes in leucine and phenylalanine kinetics produced by parenteral nutrition in premature infants. Pediatr Res 41:568-574

16. Melville S, McNurlan MA, McHardy KC, Broom J, Milne E, Calder AG, Garlick PJ 1989 The role of degradation in the acute control of protein balance in adult man: failure of feeding to stimulate protein synthesis as assessed by L-[1-13C]leucine infusion. Metabolism 38:248-255

17. Giordano M, Castellino P, DeFronzo RA 1996 Differential responsiveness of protein synthesis and degradation to amino acid availability in humans. Diabetes 45:393399

18. Denne SC, Karn CA, Ahlrichs JA, Dorotheo AR, Wang J, Liechty EA 1996 Proteolysis and phenylalanine hydroxylation in response to parenteral nutrition in extremely premature and normal newborns. J Clin Invest 97:746-754

19. Poindexter BB, Karn CA, Ahlrichs JA, Wang J, Leitch CA, Liechty EA, Denne SC 1997 Amino acids suppress proteolysis independent of insulin throughout the neonatal period. Am J Physiol 272:E592-E599

20. Kopple JD 1987 Uses and limitations of the balance technique. JPEN J Parenter Enteral Nutr 11:79S-85S

21. Tappy L, Acheson K, Normand S, Schneeberger D, Thelin A, Pachiaudi C, Riou JP, Jequier E 1992 Effects of infused amino acids on glucose production and utilization in healthy human subjects. Am J Physiol 262:E826-E833

\section{Erratum}

The abstract to the article "Circulating Interferon-gamma and White Matter Brain Damage in Preterm Infants," by Ingrid Elisabet Hansen-Pupp, et al., appearing in Pediatric Research 2005; 58:946-952 was printed with errors. Corrections to the abstract appear below. The editors regret the error.

The sentence beginning "Pro-inflammatory and modulatory ...," should read: Pro-inflammatory [tumor necrosis factor- $\alpha$ (TNF- $\alpha$ ), interferon- $\gamma$ (IFN- $\gamma$ ), IL-1 $\beta$, IL-2, IL-6, IL-8, IL-12] and modulatory (IL-4, IL-10) cytokines were analyzed from cord blood, and at 6,24 and $72 \mathrm{~h}$ postnatal age.

The sentence beginning "Severe intraventricular hemorrhage (IVH) . .," should read: Severe intraventricular hemorrhage (IVH) was associated with increase in AUC [(IL-6) and (IL-8), odds ratio (OR) 2.8 and 13.2 respectively], whereas white matter brain damage (WMD) was associated with increase in AUC (IFN- $\gamma$; OR, 26.0). 